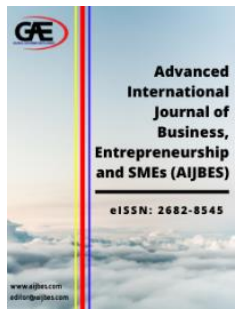

\author{
ADVANCED INTERNATIONAL JOURNAL OF \\ BUSINESS, ENTREPRENEURSHIP AND SMES \\ (AIJBES) \\ www.aijbes.com
}

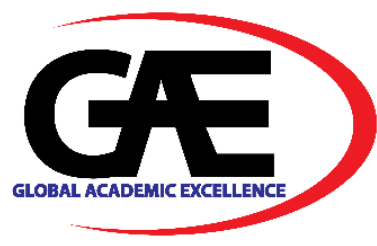

\title{
THE INFLUENCE OF E-COMMERCE' MARKETING ON IMPULSIVE BUYING BEHAVIOUR
}

\author{
Enri Nabila Bahrah ${ }^{1 *}$, Ira Fachira ${ }^{2}$ \\ 1 School of Business and Management, Institut Teknologi Bandung, Indonesia \\ Email: enri_nabila@sbm-tib.ac.id \\ 2 School of Business and Management, Institut Teknologi Bandung, Indonesia \\ Email: ira@sbm-tib.ac.id \\ * Corresponding Author
}

\section{Article Info:}

\section{Article history:}

Received date: 11.08 .2021

Revised date: 22.08 .2021

Accepted date: 12.09 .2021

Published date: 15.09.2021

\section{To cite this document:}

Bahrah, E. N., \& Fachira, I. (2021). The Influence Of E-Commerce' Marketing On Impulsive Buying Behaviour. Advanced International Journal of Business, Entrepreneurship and SMEs, 3 (9), 349-361.

DOI: $10.35631 /$ AIJBES.39023.

This work is licensed under $\underline{\text { CC BY 4.0 }}$ (c)

\begin{abstract}
:
Online impulsive buying behavior has grown in accordance with the advancement of e-commerce operations. However, despite the fact that numerous published studies have investigated some variables that influence online impulse purchase behavior, the involvement of promotional stimuli for broad diversification of products within a short period along with hedonic motivation being the moderator, as applied in e-commerce' marketing campaign activities in Indonesia, in influencing impulsive buying behavior remains unexplored. This study, using PLS-SEM statistical method and judgemental sampling technique, is advantageous to address the influence of those marketing stimuli in generating impulsive buying behavior. A quantitative method was applied in this study, using an online questionnaire targeted at online shoppers all across Indonesia. Based on the analysis, it is found that time scarcity promotion is positively influencing online impulsive buying behavior, with or without the role of high hedonic motivation as the moderator. On the other hand, a price promotion attribute's positive impact on online impulsive buying behavior is accepted as long as it does not involve the hedonic motivation as a moderator. The results of the research are intended to provide a better understanding of marketing stimuli in the research industry and practical recommendations to online merchants on how to promote their products more effectively to generate overall sales through impulsive purchases.
\end{abstract}

Keywords:

E-Commerce; Online Impulsive Buying Behavior; Marketing Stimuli; Hedonic Motivation; PLS-SEM; Quantitative Method 


\section{Introduction}

E-commerce' advancements represent a very diverse and competitive area, linked studies can be carried out over various lengths of time and trends can be analyzed over a period of time. (Chen, Su and Widjaja, 2016) summarized a variety of published research that have focused on how different variables related to information systems influence online impulse purchases within the framework of e-commerce, which includes online store beliefs (Verhagen and Van Dolen, 2011), website quality (Turkyilmaz, Erdem and Uslu, 2015), system layout (Shen and Khalifa, 2012), website attributes (Liu, Li and Hu, 2013), website atmospheric cues (Floh and Madlberger, 2013), or website ease of navigation (Lin and Lo, 2016). There are also other related variables that influence online impulse buying such as idol worshiping behavior (Park et al., 2012) and psychological distance (Liu et al., 2020). Dawson and Kim (2010) stated numerous sales incentives, gifts with transactions, free delivery, competitions or sweepstakes, quick return procedures, or concept clues, including new models, featured products, best choices, and gift suggestions, were key indicators of online impulse shopping in online apparel retailers. Recent study (Hasim, Ishak and Hassim, 2019) argued that there is a positive correlation between sales promotional stimuli and online impulse purchases.

Every year, sales on Southeast Asia's designated "Super Shopping Day" increased considerably. Not only appears on $9^{\text {th }}$ September, now Shopee has more twin dates marketing campaigns, such as 11.11 and 12.12 sale season, following the succession track of Shopee 9.9 "Super Shopping Day". Those heavy days of marketing campaigns resulted in an average of 129 million site visits per month from Indonesian shoppers in particular, and approximately 6 million to over 12 million orders being placed on Shopee across Southeast Asia, which is almost three times the average day's transaction volume. Even so, the influence of its various promotions as the marketing stimuli toward online impulsive buying still remains underexplored. Shopee's marketing campaign with diverse categories may lead to planned consumer behaviour that technically attracts more consumers who perceive it as a way to spend expenditure wisely due to appealing offers that may advantages them.

Moreover, previous study has found a supportive association between sales promotion stimuli and consumer purchasing behaviour, but it does not investigate how the sales promotion stimulus of different consumer benefits varies in their effect on impulsive transactions (Floh and Madlberger, 2013). According to the promotion's effectiveness, the previous literature stated that promotion may contribute to unplanned transactions, which are often considered to be the key source of sales growth (Zheng, Liu and Zhao, 2013). The term "impulse purchasing" refers to a sudden desire to purchase something, whereas "unplanned buying" refers to the lack of a choice prior to making a shopping transaction (Beatty and Elizabeth Ferrell, 1998). According to that, unlike unplanned transactions, with more in-depth classification, interestingly, there has been very little research of the influence of sales promotion on the impulse buying behavior, in particular the one that is carried out with a range of products and services within several weeks, as one of the e-commerce' marketing stimuli. In order to reaffirm the influence of these marketing stimuli, prior literature considered that a further analysis should examine a greater sample scale of websites with diverse types of products offered. This was a potential gap research to analyze further in e-commerce platforms with a wide variety of products and even services categories.

Online shoppers of e-commerce may not have enough time to seek for other items during the twin dates marketing campaigns due to different kinds of sales promotion applied within time restriction, thus when an item is difficult to secure, the item's value rises. Customers are Copyright (C) GLOBAL ACADEMIC EXCELLENCE (M) SDN BHD - All rights reserved 
Volume 3 Issue 9 (September 2021) PP. 349-361

DOI 10.35631/AIJBES.39023

subsequently prompted to purchase more readily to fulfill their esteem as a result of the increased value and so that individuals are more likely to seek for discounts and special deals while shopping online which this kind of behavior potentially affect customers' impulsive buying and unplanned spending (Akram et al., 2018). Past studies by Yu and Bastin (2017) and Akram et al. (2017) broadened the literature in the field of online impulsive buying and have argued that emotions, the desire to purchase for recreational activities (hedonic motivation), get in the way of the impulse buying process, with hedonic consumers being more likely to purchase impulsively. Lo, Lin and Hsu (2016) suggested that online impulsive purchasing behavior might further study the complementing impacts (moderation effect). To explain further the multidimensional function of the hedonic motivation variable in enhancing impulsive online purchase behavior, this present study covers the gap by assessing the hedonic motivation as a moderator variable.

As a response to confirm the influence of several marketing stimuli in a greater sample scale of websites with diverse types of products offered and to address the complementing impacts of hedonic motivations in influencing online impulsive buying, this research is expected to contribute towards a broader comprehension of causal relationship between sales promotion tools in generating impulsive purchases along with the hedonic motivations involved as a moderation and also to serve as a practical advice to merchants for more effective promotion to boost general sales, better decision-making and greater advantages.

\section{Literature Review}

\section{Online Impulse Buying}

The practice or action of purchasing things or services through the internet is known as online shopping (Moshref et al. 2012). It is done by searching for products or the services through the digital platform, selecting items online and organizing for delivery and payment online as well, either by online payment beforehand using a credit or debit card or upon delivery. Fernandes et al. (2021) indicated that the advancement of technology has made online shopping more convenient for customers with regard to obtaining information and recommended products, as well as searching and evaluating the information, and eventually resulting in an actual transaction. Added with the development of digital stores, online marketplaces, and internet accessibility escalation, this purchasing style quickly grows.

Lo, Lin and Hsu (2016) believed that online purchasing is an integrated embodiment of rational and irrational behavior i.e. online impulse buying with irrational online shopping behavior contributing for a significant share of e-retailer earnings. Online customers are more interested in a discreet psychological state of unplanned and spontaneous action towards a purchasedecision process, which finds it challenging for e-retailers to anticipate, added with a complexity due to the majority of online pulse purchase studies, they analyze online impulsepurchasing causes based on hypotheses stemming from information system research (Floh and Madlberger 2013).

Chan, Cheung and Lee (2017) viewed impulse purchasing as a process-outcome system within the realm of an individual psychological viewpoint that happens when a customer has a sudden, often continuous need to purchase something right away. Variety of studies have been conducted due to online impulse buying matters. Hedonic motivations, utilitarian motivations, adventure shopping, idea shopping, social shopping, perceived usefulness, perceived enjoyment, visual appeal information fit-to-task, and the need to purchase impulsively are Copyright (C) GLOBAL ACADEMIC EXCELLENCE (M) SDN BHD - All rights reserved 
Volume 3 Issue 9 (September 2021) PP. 349-361 DOI 10.35631/AIJBES.39023

several variables that impact online impulse buying, as an unplanned buying decision. (Ozen and Engizek 2013; Akram et al., 2018).

\section{Time Scarcity Promotion}

Noone and Lin (2020) defined Promotion's Limited Time Scarcity as scarcity messages driven by an indication of a more or less accurate boundary on available supply (e.g. " X only available until Y"). Wu et al. (2020) defined Limited Time Scarcity as an promotional offering that is allocated for a limited time before it becomes unavailable. Regarding those literatures, Shopee's twin date marketing campaign, such as 9.9 Super Shopping Day, is a suitable case as it offers various promotional tools for a variety of goods within restricted time. Time constraint is the scarcity appeal most commonly used in retail advertising (Shen, 2016). Moreover, a study has found that marketing-based scarcity can greatly contribute to the appeal of items (Zheng, Liu and Zhao, 2013). In fact, also some studies have shown that time scarcity can increase the consumer's impulse to purchase due to high pressure and enhanced perceived value (Li et al., 2021).

Zheng, Liu and Zhao (2013) discovered that time constraint from scarce promotion can contribute for most change in expected purchasing, whereas high-frequency promotion can induce buyer fatigue. However, using experimental design, Shen (2016) found that strong messaging contributed to higher purchasing probability than weak messages when the constraint was high, and that the shortage of product message interactions strongly represented an involvement by message intensity interaction. Future research may also examine how individuals with low and high levels of uniqueness motivation respond to scarcity control. (Roy and Sharma, 2015). As also further discussed by Soliman (2017) that scarcity enhances the impulsive purchase atmosphere by fostering a sense of urgency in customers and resulting in shorter searches, it therefore can be argued that time scarcity promotion has positive influence toward impulsive buying. Wu et al. (2020) also recommended that online retailers that want to create rivalries around their promotions employ scarcity as a tactical decision.

\section{Price Promotion Attributes}

A price-based sales promotion stimulus in which buyers are offered the exact same item at a reduced price usually is called price discounts (Xu and Huang, 2014). Consumers tend to look to benefit from low costs and want the lowest price for their items, and once they have seen the goods in a store either online or offline, they may purchase on the internet regularly (Schneider and Zielke, 2020). Also, given that price discount is contended to be a more effective precursor of impulsive buying intention (Xu and Huang, 2014) and that diversity of price features on online retailers is argued to play a significant role in online impulse buying for apparel products (Park et al., 2012), it appears that there is a presumably positive correlation between price promotion attributes and influencing online impulse buying.

\section{Hedonic Motivation}

Pleasant, inherent, and stimulation-driven purchasing motives are referred to as hedonic shopping motivations (Nguyen, Nguyen and Barrett, 2007). It has been discovered that particular types of consumer promotions can hedonically stimulate customers to shop (hedonic motivation) and generate good feelings in customers (positive affect), as both value shopping and good effect stimulate impulsive buying behavior through the creation of impulsive desires (Bandyopadhyay et al., 2021). Some of the studies have contributed to the acknowledgement that emotions control the impulse purchase decisions and impulse buying behaviour is the outcome of hedonic motivations (Yu and Bastin, 2017). Chan, Cheung and Lee (2017) 
Volume 3 Issue 9 (September 2021) PP. 349-361

DOI 10.35631/AIJBES.39023

summarized the hedonic motivation as being an impulsive consumer characteristic which therefore classified within the internal stimulus. Ozen and Engize (2014) argued that impulsive purchases may also be considered a way to alleviate stress where hedonic motives could be assessed as motivators of online purchasing and online impulsive, given that many online retailers also aim to create a hedonic atmosphere that is beneficial to many customers with many atmospheric signals that influence shopping behaviour. Their research also found that, when there are discounts, the online customers who consider online buying to be an adventure and a method to relax, are more likely to shop online impulsively.

The hedonic shopping motivations of the purchase of advertised items (immediate promotion) induce consumer stimulation that leads to the act of purchasing impulses (Bandyopadhyay et al., 2021). Positive correlation figures can be found in three dimensions of hedonic shopping motivation (relaxation, value, and adventure) and the online impulse buying phenomenon, according to the study, which also focused on how online shopping behaviors influenced by hedonic shopping motivation are related. (Chiu et al., 2014).

\section{Methodology}

This section depicts an overview of the research process, which includes exploratory research to do an exploration regarding the phenomena of e-commerce' marketing stimuli on Shopee's twin date marketing campaign, such as 9.9 Super Shopping Day and issues regarding the impulsive buying behavior toward it, followed by identifying potential concerns. Then, continued by the literature review on the results of past research and hypotheses that may aid in conducting this particular research. Also, a quantitative approach will be conducted for the data collection method, using questionnaires. Survey method used to request standardized questionnaires from a sample of the study population in order to collect information. In this study, judgmental sampling, a method of non-probability sampling in which the researcher decides units to be sampled based on their expertise and professional judgment, was used as the sampling technique. The method is chosen because the researcher will be selecting people who have been purchasing online on Shopee, specifically during Shopee's twin date marketing campaign, for instance during 9.9 Super Shopping Day at any year respectively since 2018, due to the first launching of Shopee's 9.9 Super Shopping Day in Indonesia. Followed by the findings from the questionnaire will be analysed to have conclusions and recommendations.

Partial Least Squares was utilized in this study to determine the model in the conceptual framework, compute and conclude the relationship between all variables using the SmartPLS program. The variables are time scarcity promotion and price promotion attribute as the independent variables, hedonic motivation that moderates each of time scarcity promotion and price promotion attribute with online impulsive buying behaviour, as the dependent variable. In order to accomplish the analysis, several critical phases must be accomplished, such as testing the indicator reliability, internal consistency reliability, convergent validity, and discriminant validity.

\section{Discussion and Analysis}

This study uses a framework (Figure 1) which consists of variables that correlate with impulsive buying behaviour on e-commerce marketing stimuli in this research. The framework and variables are conceptually constructed and integrated from four prior studies. The framework and variables are generated from Park et al. (2012); (Zheng, Liu and Zhao, 2013); Xu and Huang (2014); and (Soliman, 2017). Technically, this study aims for observing the influences of scarcity and price promotion attributes, by using a higher level of price reduction Copyright (C) GLOBAL ACADEMIC EXCELLENCE (M) SDN BHD - All rights reserved 
Volume 3 Issue 9 (September 2021) PP. 349-361 DOI 10.35631/AIJBES.39023

from previous study (Soliman, 2017) and also evaluating across a variety of industries/product types within, and moderating by hedonic motivation due to Shopee's twin date marketing campaign greatly known for its offering of time limited sales promotion and its price promotion attributes with hedonic motivations. The following are the conceptual framework and the developed hypothesis.

Source: Author's Interpretation

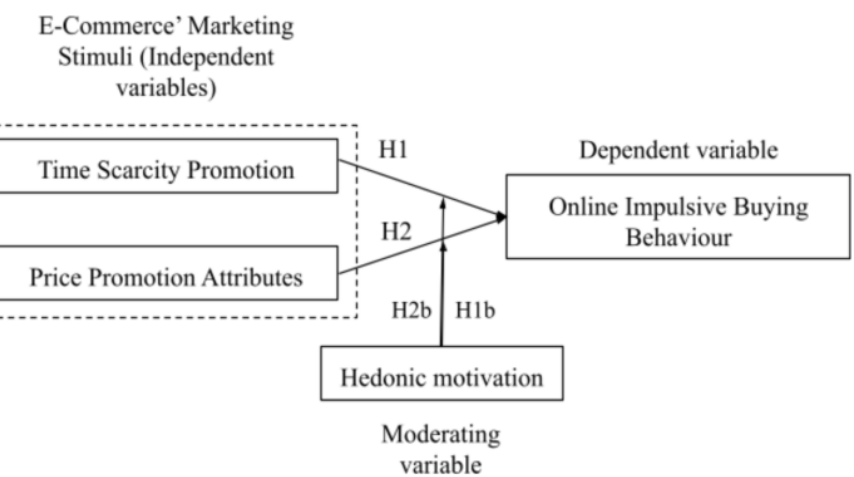

Figure 1: Conceptual Framework

H1: Time scarcity promotion has a positive influence on online impulsive buying behaviour. H1b: Time scarcity promotion's positive influence on online impulsive buying behaviour will be stronger with higher hedonic motivation. $\mathrm{H} 2$ : Price promotion attributes have a positive influence on online impulsive buying behaviour. $\mathrm{H} 2 \mathrm{~b}$ : Price promotion attributes' positive influence on online impulsive buying behaviour will be stronger with higher hedonic motivation.

\section{Effect Size (F Square)}

A comprehensive examination of the model's $f^{2}$ effect size can be performed to measure the strength of the latent variable's connection (Wong, 2013). Small, medium and high effects are seen in the effect sizes of $0.02,0.15$, and 0.35 correspondingly (Cohen, 1988). 
Volume 3 Issue 9 (September 2021) PP. 349-361 DOI 10.35631/AIJBES.39023

\begin{tabular}{|c|c|c|c|c|c|c|}
\hline & $\begin{array}{l}\text { Hedonic } \\
\text { Motivation }\end{array}$ & $\begin{array}{l}\text { Hedonic } \\
\text { Motivation } \\
\text { moderates } \\
\text { Price } \\
\text { Promotion } \\
\text { Attributes }\end{array}$ & $\begin{array}{c}\text { Hedonic } \\
\text { Motivation } \\
\text { moderates } \\
\text { Time Scarcity } \\
\text { Promotion }\end{array}$ & $\begin{array}{l}\text { Online } \\
\text { Impulse } \\
\text { Buying } \\
\text { Behavior }\end{array}$ & $\begin{array}{c}\text { Price } \\
\text { Promotion } \\
\text { Attribute }\end{array}$ & $\begin{array}{c}\text { Time } \\
\text { Scarcity } \\
\text { Promotion }\end{array}$ \\
\hline $\begin{array}{l}\text { Hedonic } \\
\text { Motivation } \\
\text { moderates } \\
\text { Price } \\
\text { Promotion } \\
\text { Attributes }\end{array}$ & & & & 0.008 & & \\
\hline $\begin{array}{c}\text { Hedonic } \\
\text { Motivation } \\
\text { moderates } \\
\text { Time Scarcity } \\
\text { Promotion }\end{array}$ & & & & 0.031 & & \\
\hline $\begin{array}{c}\text { Online } \\
\text { Impulse } \\
\text { Buying } \\
\text { Behavior }\end{array}$ & & & & & & \\
\hline $\begin{array}{c}\text { Price } \\
\text { Promotion } \\
\text { Attribute }\end{array}$ & & & & 0.035 & & \\
\hline $\begin{array}{l}\text { Time Scarcity } \\
\text { Promotion }\end{array}$ & & & & 0.281 & & \\
\hline
\end{tabular}

Table 1: Table F Square Result

Source: SmartPLS Computation

Based on Table 1 above, it can be concluded that most of the relationships between each latent variable tend to have moderate effect size. There is only one relationship between 'Hedonic Motivation moderates Price Promotion Attributes'-> 'Online Impulse Buying Behavior' that is having a small effect size. 'Time Scarcity Promotion'-> 'Online Impulse Buying Behavior' and 'Hedonic Motivation moderates Time Scarcity Promotion' -> 'Online Impulse Buying Behavior' both have moderate effect size. The one with highest effect size is 'Price Promotion Attribute' -> 'Online Impulse Buying Behavior'

\section{Simple Slope Analysis}

The regression of the result $\mathrm{y}$ on the predictor $\mathrm{x}$ for a particular value of the moderator $\mathrm{z}$ is known as a simple slope (Preacher, Curran and Bauer, 2004). The three lines shown in the Simple Slope Analysis represent the relationship between the independent variable (x-axis) and dependent variable

(y-axis). 


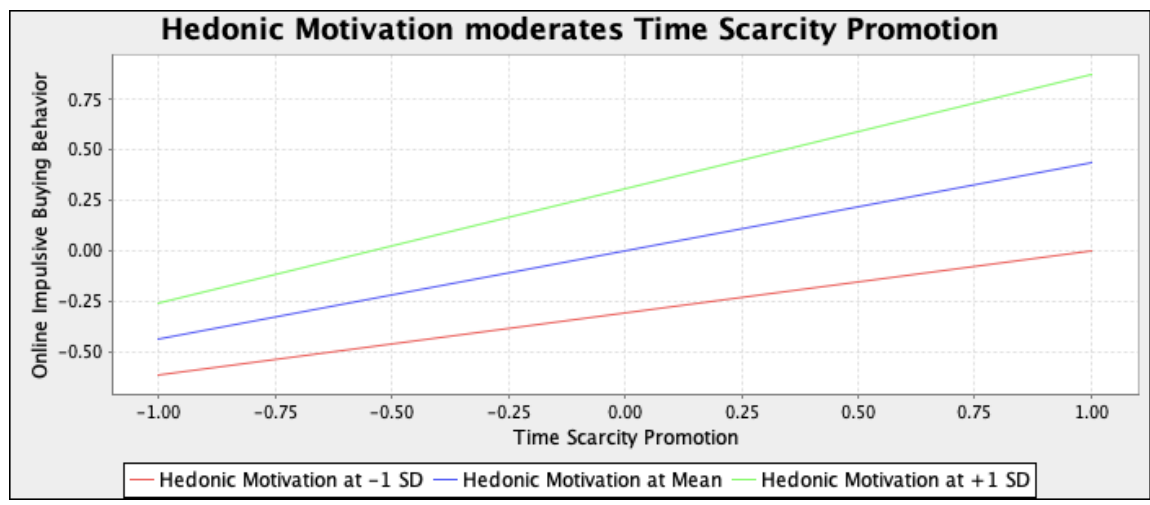

Figure 2: Interaction Plot (1)

Source: SmartPLS Computation

This research sought to determine the moderating role of hedonic motivation in moderating the relationship between time scarcity promotion and online impulsive buying behaviour. As Figure 2 shows, the line labelled for higher hedonic motivation has a steeper gradient than the lower hedonic motivation, implying that the significant positive relationship between time scarcity promotion and online impulse buying behaviour is really strengthened when hedonic motivation is high.

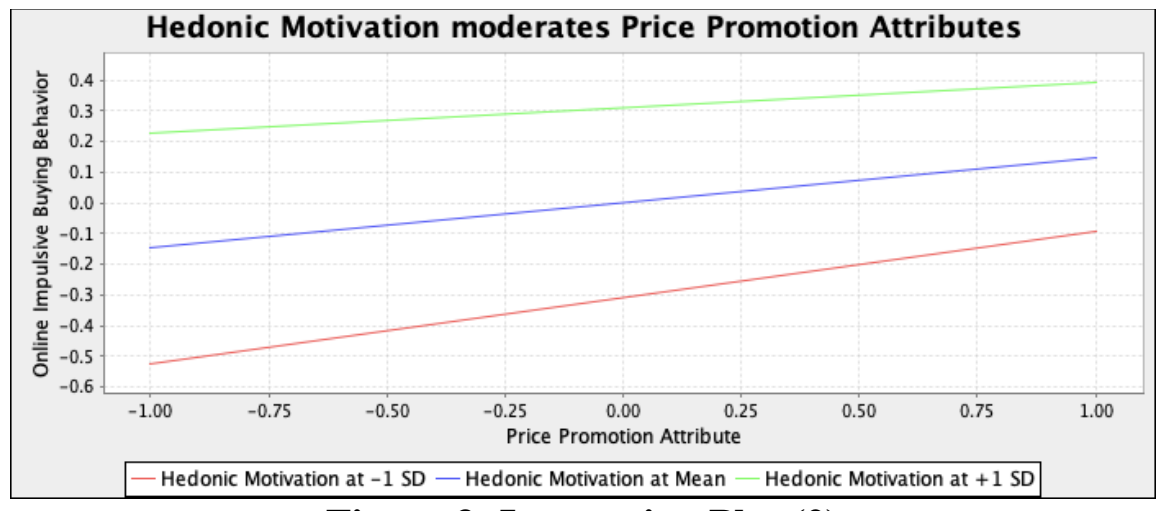

Source: SmartPLS Computation

Figure 3: Interaction Plot (2)

This research sought to determine the moderating role of hedonic motivation between price promotion attribute and online impulse buying. As can be seen in Figure 3, the line labelled for lower hedonic motivation has a steeper gradient than the higher hedonic motivation. Regarding that, the line labelled for higher hedonic motivation indicates that at higher hedonic motivation, price promotion attribute actually fails to influence online impulsive buying behaviour. The findings indicated that when hedonic motivation is low, the price promotion characteristic has a slightly larger impact on online impulsive purchase behavior.

\section{Hypothesis Testing}

Bootstrap method is performed in SmartPLS to assess the significance of both the inner and outer models of the structural path utilizing T-statistics (Wong, 2013). This approach can be utilized to assess the significance level in the hypothesis test between each of the variables measured and for the path coefficient to be perceived to be important by using a two-size ttest of 5 percent of the significant level, T-statistics must be greater than 1.96. 
Volume 3 Issue 9 (September 2021) PP. 349-361 DOI 10.35631/AIJBES.39023

\begin{tabular}{|c|l|c|c|c|}
\hline Hypothesis & \multicolumn{1}{|c|}{ Structural Path } & T-value & P-Value & Result \\
\hline H1 & $\begin{array}{l}\text { Time Scarcity Promotion -> Online } \\
\text { Impulsive Buying Behaviour }\end{array}$ & 9.902 & 0 & Accepted \\
\hline H1b & $\begin{array}{l}\text { Hedonic Motivation moderates Time } \\
\text { Scarcity Promotion -> Online } \\
\text { Impulsive Buying Behaviour }\end{array}$ & 3.008 & 0.001 & Accepted \\
\hline H2 & $\begin{array}{l}\text { Price Promotion Attribute -> Online } \\
\text { Impulsive Buying Behaviour }\end{array}$ & 3.192 & 0.001 & Accepted \\
\hline H2b & $\begin{array}{l}\text { Hedonic Motivation moderates Price } \\
\text { Promotion Attribute -> Online } \\
\text { Impulsive Buying Behaviour }\end{array}$ & 1.49 & 0.068 & Rejected \\
\hline
\end{tabular}

Table 2: Hypothesis Testing

Source: Author's Analysis

Hypothesis 1 proves that this hypothesis is acceptable. It is shown that the restriction of time promotion given within twin date marketing stimuli have a significant contribution in influencing the impulsive buying behaviour of the online shoppers. This is also in accordance with earlier study by Soliman (2017) which indicated that marketing-based scarcity may make a big contribution to attraction for products leading to impulsive online shopping. The result therefore is in accordance with previous research by Li et al. (2021) which support the statement that time constraints can enhance the consumer's impulsive buying.

Hypothesis $1 \mathrm{~b}$ also proves that this hypothesis is acceptable. By assessing its effect size and moderating evaluation, it can be claimed that the moderation effect of hedonic motivation gives a significant impact on time scarcity promotion in influencing the impulsive buying behaviour of the online shoppers. The simple slot analysis proved that the more intense the hedonic motivation, in this study it refers to the behaviour of enjoying spending time and shopping online, the stronger the influence of time scarcity promotion on online impulsive buying behaviour. It implies that higher motivation within online shoppers to enjoy being able to be in e-commerce, spending their time within, and even shopping online, which primarily find online shopping as a recreational activity, strengthens the positive affect of time scarcity promotion and online impulsive buying behaviour. On the other hand, for online shoppers who do not find online shopping as a way to alleviate their stress or tend to not claim online shopping as their recreational activity, their low hedonic motivation still has a positive effect on their online impulsive buying behaviour, but it is a weaker positive effect compared to those with higher hedonic motivation. This findings also supports prior research by Bandyopadhyay et al. (2021), which found that the hedonic shopping motivation of shopping promoted (timely promotion) products generates consuming impulses and therefore encourages impulsive purchase. This study also aligns with the study by Akram et al. (2018) which confirmed that value shopping, feeling happy and delighted when acquiring a good deal of purchase that is a part of hedonic motivation, has a significant influence on scarcity promotion and thus, influencing the online impulsive buying behaviour. This research confirms previous research by Ozen and Engize (2014), who found that customers at ecommerce platforms are at a bit more time constraint as they should make a quick decision to purchase within a short timespan or potentially lose the goods. Moreover, this study validates the previous finding by specifying the occurring circumstance within marketing campaigns as a part of marketing stimuli. When impulsive customers are considering an unanticipated purchase, they tend to enhance their chance of gaining the goods because they are likely to pursue a hedonic goal-seeking attitude under time constraint. 
Volume 3 Issue 9 (September 2021) PP. 349-361 DOI 10.35631/AIJBES.39023

Hypothesis 2 stated that price promotion attributes have a positive influence on online impulsive buying behaviour. The result demonstrates that this hypothesis is acceptable since it generates a significant outcome. It is shown that price-based sales promotion stimuli given within twin date marketing stimuli have a significant contribution in influencing the impulsive buying behaviour of the online shoppers. This result is also supported by the greatest effect size it has in directly influencing online impulsive buying. The result also aligns with past research that has shown that price reduction is seen to be a more efficient determinant of impulsive buying behaviour (Xu and Huang, 2014). Furthermore, this study is consistent with previous research by Park et al. (2012), which found that price attributes have a significant impact on online impulse buying behaviour; added to that, unlike their previous studies, this study did not focus on apparel products but rather a broad range of products.

Hypothesis $2 \mathrm{~b}$ stated that the price promotion attribute's positive influence on online impulsive buying behaviour will be stronger with higher hedonic motivation. Since the result for this hypothesis is not giving a significant result as expected, therefore this hypothesis is rejected. This is a surprising result considering that his finding does not support the earlier empirical research by $\mathrm{Xu}$ and Huang (2014) which showed that a sales promotion is a more efficacious stimulus for online impulsive intentional purchasing, especially for hedonic and relatively inexpensive products. This study also does not meet the requirement to support the previous research by Ozen and Engize (2014), who stated that when there are discounts, online shoppers who view online shopping as an adventure and a way to relax are less likely to avoid shopping online impulsively. This may be caused of the hedonic motivation's role as the moderating variable where it was commonly used in the previous researches as the mediating variable or simply as the exogenous latent variable, as it appeared in the previous studies respectively (Zheng et al., 2019) (Chiu et al., 2014). By assessing its effect size and moderating evaluation, however the moderation effect of hedonic motivation is considerably small and gives an insignificant impact on price promotion attributes in influencing the impulsive buying behaviour of the online shoppers. As can be seen in Figure 3, the simple slot analysis proved that at high levels of hedonic motivation, in this study it refers to the behaviour of enjoying spending time and shopping online, price promotion attributes are unproductive on influencing online impulsive buying behaviour. This is a quite interesting result as the line labelled for lower hedonic motivation happens to have a steeper gradient than the higher hedonic motivation, implying that the significant positive relationship between time scarcity promotion and online impulse buying behaviour is really strengthened when hedonic motivation is low. Simply put, for online shoppers with lower hedonic motivation, who do tend to be less finding online shopping as a way to alleviate their stress or tend to not claim online shopping as their recreational activity, the price promotion attribute which means the discount given within the marketing campaign has a greater positive affect on impulsive buying behaviour. However, the behavioural descriptive findings of this study accordance with previous research findings (Roy \& Ng, 2012), which show that when making comparisons two products, - especially since this study specifies the different kinds of products' brand claims, shoppers are more engaged with the goods with hedonic attributes and share a natural tendency for the product with the hardest hitting hedonic claims.

\section{Conclusions}

The significant result from the moderating effect of hedonic motivation only shows in the relationship between time scarcity promotion and online impulse buying behaviour. At higher levels of hedonic motivation, the greater the relationship is. However, it does not apply when it comes to the other moderating relationship. With low effect size and insignificant impact of 
Volume 3 Issue 9 (September 2021) PP. 349-361

DOI 10.35631/AIJBES.39023

hedonic motivation within the relationship, this study proved that hedonic motivation does not meet the criteria as a moderator role to price promotion attributes in influencing online impulse buying behaviour. Despite that, price promotion attributes are evidently shown to have a positive direct influence on online impulse buying, without any moderating effect from hedonic motivations. However, the price promotion attribute happens to have a considerably high effect size in terms of its score classification and it even is being the greatest effect size for directly influencing online impulsive buying behaviour. To conclude, with the moderation effect from hedonic motivation, time scarcity promotion has a bigger impact in influencing online impulsive buying behaviour compared to price promotion attributes. In other words, time scarcity promotion thus can be implied as the type of promotional stimuli that mostly affects the online impulsive buying. The implications of this study can be claimed as the recommendations for online merchants in creating new marketing strategies that are expected for generating sales during the twin date marketing campaign that is gradually being held by ecommerce, in this case especially Shopee.

\section{References}

Akram, U., Hui, P., Khan, M., Yan, C., \& Akram, Z. (2018). Factors Affecting Online Impulse Buying: Evidence from Chinese Social Commerce Environment. Sustainability, 10(2), 352. doi:10.3390/su10020352

Akram, U., Hui, P., Khan, M. K., Tanveer, Y., Mehmood, K., \& Ahmad, W. (2018). How website quality affects online impulse buying. Asia Pacific Journal of Marketing and Logistics, 30(1), 235-256. doi:10.1108/apjml-04-2017-0073

Akram, U., Hui, P., Khan, M. K., Saduzai, S. K., Akram, Z., \& Bhati, M. H. (2017). The plight of humanity: Online impulse shopping in China. Human Systems Management, 36(1), 73-90. doi:10.3233/hsm-171768

Asyraf, M., Ishak, M. F., \& Hassim, A. A. (2019, October 21). The Relationship between Online Shopping Environments, Sales Promotions, Website Quality, and Impulsive Buying Behaviour: A Structural Equation Modelling Approach. Retrieved from https://zenodo.org/record/3514948\#.YRKoiVMzYc8

Bandyopadhyay, N., Sivakumaran, B., Patro, S., \& Kumar, R. S. (2021). Immediate or delayed! Whether various types of consumer sales promotions drive impulse buying?: An empirical investigation. Journal of Retailing and Consumer Services. https://doi.org/10.1016/j.jretconser.2021.102532

Beatty, S. E., \& Ferrell, M. E. (1998). Impulse buying: Modeling its precursors. Journal of Retailing, 74(2), 161-167. doi:10.1016/s0022-4359(98)90009-4

Chan, T. K. H., Cheung, C. M. K., \& Lee, Z. W. Y. (2017). The state of online impulse-buying research: A literature analysis. Information and Management, 54(2), 204-217. https://doi.org/10.1016/j.im.2016.06.001

Chen, J. V., Su, B., \& Widjaja, A. E. (2016). Facebook C2C social commerce: A study of online impulse buying. Decision Support Systems, 83, 57-69. doi:10.1016/j.dss.2015.12.008

Chiu, C. M., Wang, E. T. G., Fang, Y. H., \& Huang, H. Y. (2014). Understanding customers' repeat purchase intentions in $\mathrm{B} 2 \mathrm{C}$ e-commerce: The roles of utilitarian value, hedonic value and perceived risk. Information Systems Journal. https://doi.org/10.1111/j.13652575.2012.00407.x

Cohen, J. (1988). Statistical Power Analysis for the Behavioral Sciences (Vol. 3). Retrieved from http://repositorio.unan.edu.ni/2986/1/5624.pdf 
Volume 3 Issue 9 (September 2021) PP. 349-361 DOI 10.35631/AIJBES.39023

Dawson, S., \& Kim, M. (2010). Cues on apparel web sites that trigger impulse purchases. Journal of Fashion Marketing and Management: An International Journal, 14(2), 230246. doi:10.1108/13612021011046084

Fernandes, S., Venkatesh, V. G., Panda, R., \& Shi, Y. (2021). Measurement of factors influencing online shopper buying decisions: A scale development and validation. Journal of Retailing and Consumer Services. https://doi.org/10.1016/j.jretconser.2020.102394

Floh, A., \& Madlberger, M. (2013). The role of atmospheric cues in online impulse-buying behavior. Electronic Commerce Research and Applications, 12(6), 425-439. doi:10.1016/j.elerap.2013.06.001

Hasim, M. A., Ishak, M. F., \& Hassim, A. A. (2019). The relationship between online shopping environments, sales promotions, website quality, and impulsive buying behaviour: A structural equation modelling approach. International Journal of Innovation, Creativity and Change, 6(9). https://doi.org/10.5281/zenodo.3514948

Liu, Q., Zhang, X., Huang, S., Zhang, L., \& Zhao, Y. (2020). Exploring Consumers\&\#8217; Buying Behavior in a Large Online Promotion Activity: The Role of Psychological Distance and Involvement. Journal of Theoretical and Applied Electronic Commerce Research, 15(1), 0-0. doi:10.4067/s0718-18762020000100106

Liu, Y., Li, H., \& Hu, F. (2013). Website attributes in urging online impulse purchase: An empirical investigation on consumer perceptions. Decision Support Systems, 55(3), 829-837. doi:10.1016/j.dss.2013.04.001

Lo, L. Y., Lin, S., \& Hsu, L. (2016). Motivation for online impulse buying: A two-factor theory perspective. International Journal of Information Management, 36(5), 759-772. doi:10.1016/j.ijinfomgt.2016.04.012

Moshrefjavadi, M. H., Dolatabadi, H. R., Nourbakhsh, M., Poursaeedi, A., \& Asadollahi, A. (2012). An Analysis of Factors Affecting on Online Shopping Behavior of Consumers. International Journal of Marketing Studies, 4(5). doi:10.5539/ijms.v4n5p81

Nguyen, T. T., Nguyen, T. D., \& Barrett, N. J. (2007). Hedonic shopping motivations, supermarket attributes, and shopper loyalty in transitional markets. Asia Pacific Journal of Marketing and Logistics, 19(3), 227-239. doi:10.1108/13555850710772914

Noone, B. M., \& Lin, M. S. (2020). Scarcity-Based Price Promotions: How Effective are they in a Revenue Management Environment? Journal of Hospitality \& Tourism Research, 44(6), 883-907. doi:10.1177/1096348020917734

Ozen, H., \& Engizek, N. (2014). Shopping online without thinking: Being emotional or rational? Asia Pacific Journal of Marketing and Logistics, 26(1), 78-93. doi:10.1108/apjml-06-2013-0066

Park, E. J., Kim, E. Y., Funches, V. M., \& Foxx, W. (2012). Apparel product attributes, web browsing, and e-impulse buying on shopping websites. Journal of Business Research, 65(11), 1583-1589. doi:10.1016/j.jbusres.2011.02.043

Preacher, K. J., Curran, P. J., \& Bauer, D. J. (2004). Simple Intercepts, Simple Slopes, and Regions of Significance in MLR 2-Way Interactions.

Roy, R., \& Ng, S. (2012). Regulatory focus and preference reversal between hedonic and utilitarian consumption. Journal of Consumer Behaviour, 11(1), 81-88. doi:10.1002/cb.371

Roy, R., \& Sharma, P. (2015). Scarcity Appeal in Advertising: Exploring the Moderating Roles of Need for Uniqueness and Message Framing. Journal of Advertising, 44(4), 349-359. doi:10.1080/00913367.2015.1018459 
Volume 3 Issue 9 (September 2021) PP. 349-361 DOI 10.35631/AIJBES.39023

Schneider, P. J., \& Zielke, S. (2020). Searching offline and buying online - An analysis of showrooming forms and segments. Journal of Retailing and Consumer Services, 52, 101919. doi:10.1016/j.jretconser.2019.101919

Shen, F. (2016). Information congruity in scarcity appeal: A structural equation modeling study of time-limited promotions. Journal of Marketing Communications, 22(2), 135-154. doi:10.1080/13527266.2013.828770

Soliman, M. A. (2017). The Impact of Scarcity Message on Impulsive Purchase Intention Among Smartphone Shoppers. In ProQuest Dissertations and Theses.

Shen, K. N., \& Khalifa, M. (2012). System design effects on online impulse buying. Internet Research, 22(4), 396-425. doi:10.1108/10662241211250962

Soliman, M. A. (2017). The Impact of Scarcity Message on Impulsive Purchase Intention Among Smartphone Shoppers. ProQuest Dissertations and Theses.

Turkyilmaz, C. A., Erdem, S., \& Uslu, A. (2015). The Effects of Personality Traits and Website Quality on Online Impulse Buying. Procedia - Social and Behavioral Sciences, 175, 98-105. doi:10.1016/j.sbspro.2015.01.1179

Verhagen, T., \& Dolen, W. V. (2011). The influence of online store beliefs on consumer online impulse buying: A model and empirical application. Information \& Management, 48(8), 320-327. doi:10.1016/j.im.2011.08.001

Wong, K. K. K.-K. (2013). 28/05 - Partial Least Squares Structural Equation Modeling (PLSSEM) Techniques Using SmartPLS. Marketing Bulletin, 24(1).

Wu, Y., Xin, L., Li, D., Yu, J., \& Guo, J. (2021). How does scarcity promotion lead to impulse purchase in the online market? A field experiment. Information \& Management, 58(1), 103283. doi:10.1016/j.im.2020.103283

Xu, Y., \& Huang, J. (2014). Effects of Price Discounts and Bonus Packs on Online Impulse Buying. Social Behavior and Personality: An International Journal, 42(8), 1293-1302. doi:10.2224/sbp.2014.42.8.1293

Yu, C., \& Bastin, M. (2017). Hedonic Shopping Value and Impulse Buying Behavior in Transitional Economies: A Symbiosis in the Mainland China Marketplace. Advances in Chinese Brand Management, 316-330. doi:10.1057/978-1-352-00011-5_14

Zheng, X., Men, J., Yang, F., \& Gong, X. (2019). Understanding impulse buying in mobile commerce: An investigation into hedonic and utilitarian browsing. International Journal of Information Management, 48. https://doi.org/10.1016/j.ijinfomgt.2019.02.010

Zheng, X., Liu, N., \& Zhao, L. (2013). A study of the effectiveness of online scarce promotion - Based on the comparison of planned buying and unplanned buying. Wuhan International Conference on 247-257. http://aisel.aisnet.org/whiceb2013/51 